\title{
Internet and Economic Growth-Evidence from Chinese Provincial Panel Data
}

\author{
Yuan Feng \\ School of Economics, Jinan University, Guangzhou, China \\ Email: fengyuanamerican@gmail.com
}

Received 1 July 2016; accepted 23 July 2016; published 26 July 2016

Copyright (C 2016 by author and Scientific Research Publishing Inc.

This work is licensed under the Creative Commons Attribution International License (CC BY). http://creativecommons.org/licenses/by/4.0/

(c) (i) Open Access

\begin{abstract}
As the "Internet +" strategy having been put forward, the internet and other information and communication technologies will help play more important role in Chinese economic growth. This research uses Chinese provincial panel data between 2000-2014 to study the relationship between the internet communication technology and economic growth within a Cobb-Douglas function under the Solow model. The result indicates that the development of the internet communication technology has a significant role in promoting economic growth in China. At the same time, the human capital has positive interaction effect on the adjustment between the internet and economic growth. So China should continue to increase investment on the internet communication technology and infrastructure construction, and pay more attention to personnel training to promote the sustainable development of economy in China.
\end{abstract}

\section{Keywords}

Economic Growth, Internet, Human Capital

\section{Introduction}

Premier Li Keqiang proposed to develop the great China "Internet +" plan action on the third session of the $12^{\text {th }}$ National People's Congress on March 5, 2015. Generally speaking, strategy of the "Internet +" means that it combine traditional industry and the Internet through communication technology and the internet platforms to achieve a new economic performance, especially in the tertiary industry. And then it gradually penetrated into the first and the second industry. Under the background of the "new normal" economy, on the one hand, the quality of provincial and municipal economic growth is continuously adjusting and changing [1]; on the other hand, Chinese economy may be slowed by the aging of its population, and may lead to a "demographic dividend" in coming decades. There China need find new direction to shift the way of economic growth, and the internet 
and communication technology information science, as an important branch of science and technology, maybe can play such important role to stimulate economic growth. Therefore, this research has strong practical significance in providing policy implications.

\section{Literature Review}

Since the generation of the internet communication technology (ICT), the impact of ICT on society has always been a controversial academic topic, Haywood (1998) emphasized the negative impact of the abusing, misusing of ICT and the digital gap [2]; Kim (2013) highly stressed the positive role of the ICT development in improving human society and living standards in recent years [3], some scholars have studied whether the ICT is a new motivation to promote the development of social economy. In the context of the information society, the empirical researches on studying how ICT promote the economic growth have become one of the most important and popular studying direction. On the one hand, the ICT has affected human society probably only several decades, there exists a certain development space; on the other hand, Lasswel (1971) pointed out that the ICT can make different influences on the development of the country in different national policies and social environment, so it is necessary to do related research to different regions and countries [4].

There are main two research method applying in related research of the ICT and economic growth. One is based on the research of cross section data to investigate the role of the ICT to improve national competition and economic growth in different regions and countries; the other is based on time sequence to research the relationship between each variable.

Pohjola (2000) studied the effects of information technology investment on economic growth in a transversal section of 39 countries during a period from 1980 to 1995 by applying an explicit economic growth model through an extended version of the neoclassical Solow growth model. The results indicated that physical capital is a key factor of economic growth for both developed and developing countries [5]. Chu (2005) claim there exists significant positive correlation between profits produced by I CT service and its GDP growth in New Zealand based on the cross-section data of 1987-2001, therefore increasing I CT investment has a great significance on economic growth [6]. Neira (2007) performed a study of 19 OECD countries during a period from 1965 to 1990 and analyzed the direct effects of education on the production function per capital via a Cobb-Douglas production function, which considered GDP per capital and the educational level of the population and found that human capital had a doubly positive effect on the GDP per capital and that education also affected labor productivity [7]. West (2011) studied two representations of technology, the generation of innovation and the creation of economic prosperity and find that an innovative economy can be created and long-term prosperity can be sustained [8]. Salahuddin and Alam (2015) examine the short- and long-run effects of the Internet usage and economic growth on electricity consumption using annual time series data for Australia for the period 19852012 [9].

Domestically, the researches on relationship between the ICT and economic growth are late and limited. Teng Li et al. (2006) evaluate the level of regional informatization from information infrastructure and information industry, and comparative analyze its relationship of the regional economic. It turned out that the informationization slow down resources flow trend from the Midwest to the east and left development space for less developed areas [10]. Zhang Yue and Li Qi (2009) find that the elasticity of the Internet penetration to growth is 0.17 and the elasticity of broadband port number to economic growth is 0.09 , so the role of the Internet cannot be ignored based on 2006 provincial panel data [11]. Liu Yong (2010) evaluate the fixed capital stock of highway and waterway transportation's impact on economic growth in China based on provincial panel data and production function, space and time lag of spillover model. It shows ICT has a positive effect on regional economic growth, but there exists difference in regions and times [12]. He Zhong, Wu Zidong, Chen Xia and Lv Tingyan (2013) quantify the impact of broadband on economic growth and solve the endogeneity problem between broadband and economic growth, simultaneous equations model which combines macro output equation and micro supply and demand equation of broadband is constructed, and empirical analysis is made based on the data from the year of 2001-2010. Empirical analysis shows that the rate of broadband penetration each increases by $10 \%$, and the growth rate of national economy will be raised by $0.424 \%$ [13]. Zhang Yong (2014) calculated that the contribution of the Internet on an average annual GDP growth rate has reached 1.54 percent, and the contribution rate has reached $12.45 \%$, indicating that the internet is an integral part of the new engine of economic growth in 11 years [14]. Liu Hu and Zhang Jiaping (2016) find the ICT has significant role in promoting 
economic growth in China on supply and demand balance model [15].

However, in the domestic studies on economic growth, we can find that some factors of the Internet are not taking into consideration, some reflected the relationship between the ICT and economic growth from the viewpoint of information, technology, the literature directly focus on the relationship of the Internet and economic growth are few; some of the study are from the perspective of theory, some analyze the correlation of each single Internet index and economic, some analyze cross section data of a given year, there lack systematic, comprehensive and empirical research, but it is important. Therefore, our search uses the newest provincial panel data from 2000 to 2014 to quantificate the ICT economic effects. The most important contribution to academic significance is that this paper calculates a comprehensive Internet Development Index to evaluate the development level of the internet which is combined main variable of netizen numbers, site numbers and $\mathrm{CN}$ domain name numbers compared to single variable.

\section{Theoretical Analysis of the Relationship between the Internet Communication Technology and Economic Growth}

Firstly, the internet creates a huge domestic commercial market to E-commerce business. E-commerce service can provide all kinds of related services, including platform services, consulting services, tools, software services, data services, marketing services, and so on, to all individuals and enterprises, especially offering an important platform for some traditional industry which can prompt traditional industry's production efficiency, optimize its organization management mode.

Secondly, the openness and freedom of the Internet makes the more frequently and rapidly spread of information and communication, which promoted the technical innovation, and provide a good channel to the spread of new technologies. In the era of economic globalization, the traditional industry wants to keep the original advantage or to seek greater development, must adapt to the rhythm of the new era, constantly updated technology to ensure the competitiveness of the product itself, this causes the traditional industry constantly improve the production efficiency, better adapt to the change of economic environment.

Thirdly, the internet has strong positive externalities. The Internet is not a mode of economic growth within a only one industry, but to learn from each other between different industries, the atmosphere of competition with each other, learn from each other, so that the whole regional knowledge and information production can be improved, eventually, it will contribute to improve all industry to a higher level within the region.

\section{Descriptive and Methodological Section}

\subsection{Model Specification}

By selecting the model constructed on the ground of classical Cobb-Douglas Function, the paper considers the education level of labor force into human capital and material capital. The basic model is model 1 shown below.

$$
Y_{i t}=A_{i t} * K_{i t}^{\alpha} * H_{i t}^{\beta} .
$$

This is a "basic" model of Cobb-Douglas Function. $Y_{i t}$ is real GDP to represent economic growth. $K_{i t}$ is physical capital, calculated by the Perpetual Inventory Method (Goldsmith). $H_{i t}$ is average educated years of nation to measure human capital. The purpose of this study is to analyze the Internet factors driving economic growth. Therefore, it is necessary to consider these factors in the research. At the same time in order to analyze the effects of different factors on economic growth more comprehensively , the is paper take R\&D investment, marketization level, transportation into consideration, so we utilizes the total factor productivity (TFP) method to alter the original function, thus constructing the growth model needed in this research. $A_{i t}$ is total factor productivity (TFP). We define the TFP as follows.

$$
A_{i t}=A e^{\left(\rho I n t_{i t}+\delta M_{i t}+\eta l n T e c h_{i t}+\theta L n t r a n_{i t}+\lambda_{i}+\varepsilon_{i t}\right)} .
$$

Int $_{i t}$ measures the Internet development degree, $M_{i t}$ measures the degree of marketization, $\operatorname{lnTech}{ }_{i t}$ measures the technology progress, $\operatorname{Tran}_{i t}$ measure transportation capacity. $\lambda_{i}$ is on behalf of the provincial fixed effects which is determined by the provincial economic development, in the short term, it is not affected by time; $\varepsilon_{i t}$ is random perturbation terms. Connecting (1) and (2) functions, applying Log function, we can obtain the final model is as follows [15]. 


$$
\begin{gathered}
\operatorname{LnY}_{i t}=\operatorname{LnA}+\alpha \operatorname{LnK}_{i t}+\beta \operatorname{LnH}_{i t}+\rho \operatorname{Int}_{i t}+\lambda_{i}+\varepsilon_{i t} \\
L n Y_{i t}=\operatorname{Ln} A+\alpha \operatorname{LnK}_{i t}+\beta \operatorname{LnH}_{i t}+\rho \operatorname{Int}_{i t}+\delta M_{i t}+\eta \operatorname{lnTech}{ }_{i t}+\theta \operatorname{Lntran}_{i t}+\lambda_{i}+\varepsilon_{i t} .
\end{gathered}
$$

Model 3 is a very simple model without other factors, while model 4 is on econometric model with all factors to examine the internet's impact on economic growth in this paper.

\subsection{Data Analysis}

Given the data availability, this article selects a provincial panel data analysis from 2000 to 2014 except Tibet, Hong Kong, Macao and Taiwan provinces.

Internet development index is present by Int $_{i t}$. This paper uses the Principal Component Analysis (PCA) method to analyze three unilateral indicators of Internet-netizen number, site number and CN domain name number and make an eigenvector calculation before making the normalization processing about calculation result data of principal component eigenvector, so as to facilitate quantitative analyses [14]. This comprehensive indicator can represent the overall development degree of regional Internet, which is called internet development index. The netizen numbers, site numbers and CN domain names are from CNNIC Published $33^{\text {th }}$ and $37^{\text {th }}$ China Internet network development state statistic report.

The economic output is present by Lngdp which is the log function of GDP (gross domestic product). This paper use real GDP and treat GDP in 2000 as basic year to deflate the current GDP. The material capital is present by $L n k_{i t}$ which is the log function of fixed assets investment. The human capital is present by $\mathrm{LnH}_{i t}$ which is calculated by the illiteracy rate of people who are over 15 years old. The Transportation level is present by Lntran $_{i t}$ which is calculated by the log function of train miles which are multiplied by 14.7, plus road miles and divide total population. These data-current GDP, material capital, the illiteracy rate over 15 years old, population, train miles and road miles-are from China Statistic Yearbook from 2000 to 2014.

The market level is present by $M_{i t}$ which is marketalization index published by National Economical Research Institute from 2000 to 2009. The next 5 years data are predicted by regression analysis through stata.

The technology progress is present by Lntech $_{\text {it }}$ which is the log function of R\&D inner expenditure which are from China Statistical Yearbook on Science and Technology from 2000 to 2014.

The descriptive statistics of all variables are shown on Table 1.

\section{Results and Discussion}

\subsection{Basic Regression}

In order to figure out the correlation of GDP and the internet development index, this paper make a correlation analysis. From Figure 1, there is an explicit positive correlation between GDP and the Internet development index. In details, the Internet development index is indirect proportion to growth of gross domestic product. Base on this observation, the OLS regression are necessary to learn more details.

The regression models are divided into fix effect and random effect. In order to ensure the robustness of the regression results, two methods are used to analyze the panel data: with controls, such as marketization level, technology progress, transportation level, and without controls (as shown on Table 2).

Table 1. The descriptive statistics.

\begin{tabular}{cccccc}
\hline Variables & Count & Mean & Min & Max & Sd \\
\hline Lngdp & 450 & 8.7706 & 5.5744 & 11.1245 & 1.1000 \\
Lnk & 450 & 8.1573 & 5.0561 & 10.6572 & 1.1893 \\
LnH & 450 & 1.9015 & 0.3784 & 3.2363 & 0.6040 \\
Internet index & 450 & 0.6182 & 0.0000 & 1.0000 & 0.2132 \\
Market index & 450 & 6.8675 & 2.3700 & 14.7800 & 2.3496 \\
Lntech & 450 & 11.7910 & 7.6266 & 16.5384 & 1.4150 \\
Lntrans & 450 & 6.4210 & 4.0354 & 12.0081 & 1.2194 \\
\hline
\end{tabular}


Table 2. Results of the two regressions.

\begin{tabular}{|c|c|c|c|c|}
\hline Dependent Variation & (1) without controls & (2) without controls & (3) with controls & (4) with controls \\
\hline \multirow[t]{2}{*}{ Lnk } & $0.5487^{* * *}$ & $0.0903^{* * *}$ & $0.3878^{* * *}$ & $0.1009^{* * *}$ \\
\hline & $(0.0324)$ & $(0.0151)$ & $(0.0182)$ & $(0.0168)$ \\
\hline \multirow[t]{2}{*}{$\mathrm{LnH}$} & $-0.0570^{*}$ & $-0.0992^{* * *}$ & $-0.1594^{* * *}$ & $-0.0928^{* * *}$ \\
\hline & $(0.0335)$ & $(0.0330)$ & $(0.0179)$ & $(0.0337)$ \\
\hline \multirow[t]{2}{*}{ Internet index } & $1.8524^{* * *}$ & $0.2073^{*}$ & $0.9413^{* * *}$ & $0.2500^{* *}$ \\
\hline & $(0.1867)$ & $(0.1091)$ & $(0.1193)$ & $(0.1165)$ \\
\hline \multirow[t]{2}{*}{ Market index } & & & $0.0937^{* * *}$ & $0.0169^{* *}$ \\
\hline & & & (0.0069) & $(0.0082)$ \\
\hline \multirow[t]{2}{*}{ Lntech } & & & $0.4257^{* * *}$ & 0.0136 \\
\hline & & & $(0.0125)$ & $(0.0553)$ \\
\hline \multirow[t]{2}{*}{ Lntrans } & & & $-0.4292^{* * *}$ & -0.0244 \\
\hline & & & $(0.0149)$ & $(0.0605)$ \\
\hline \multirow[t]{2}{*}{ Constant } & $3.2580^{* * *}$ & & $2.4209^{* * *}$ & \\
\hline & (0.1999) & & $(0.1356)$ & \\
\hline Fixed effects & no & yes & no & yes \\
\hline $\mathrm{N}$ & 450 & 450 & 450 & 450 \\
\hline adj. $\mathrm{R}^{2}$ & 0.898 & 0.994 & 0.974 & 0.994 \\
\hline
\end{tabular}

Note: Standard errors in parentheses. ${ }^{*} \mathrm{p}<0.10,{ }^{* *} \mathrm{p}<0.05,{ }^{* * *} \mathrm{p}<0.01$ t. It is drawn by Stata.

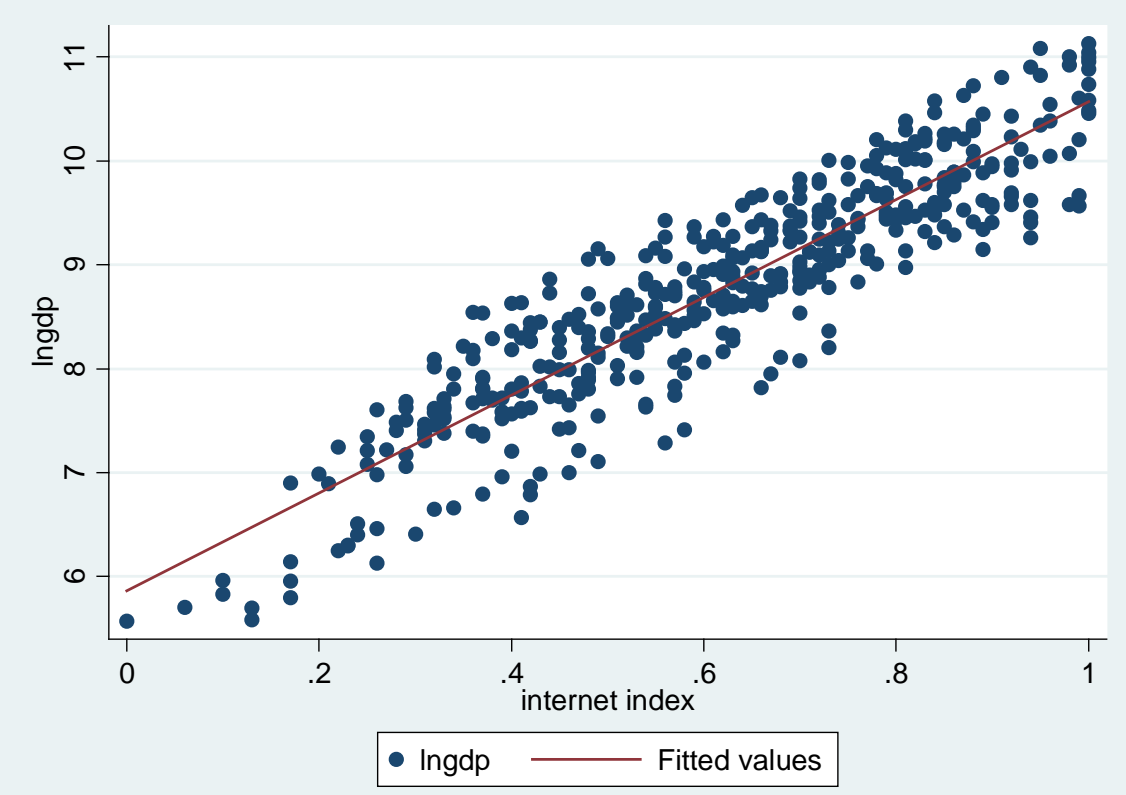

Figure 1. Relationship between LnGDP and the Internet development index. Note: The $\mathrm{x}$ axis represents the Internet development index and the y axis means the log of real GDP. And it is drawn by Stata. Our data is from China Statistical Year book ranging from 2000 to 2014 and Zhang Yong's paper (2014).

Table 2 shows us a large number of information about the regression. In line 1, the regression model is random effect model without controls. We can find that the coefficient of the internet index is positive and signifi- 
cant in $1 \%$ significance level. And the coefficient of the illiteracy rate is negative and significant in $10 \%$ significance level. These tell us that the internet communication technology and human capital are other important factors to stimulate the economic growth. In line 2, the regression model is fixed effect model without controls. We can find that the coefficient of the internet index is also positive and significant in $1 \%$ significance level, but the value is big different to line 1 . And the coefficient of the illiteracy rate is also negative and significant in $1 \%$ significance level. Comparing the value of adjustment $\mathrm{R}^{2}$ between line 1 and line 2, we can find that the line 2 is more than line 1 which means the fixed model is better to analyze this causality relationship. In line 3 , the regression model is random effect model with controls. We can find that the coefficient of the internet index is positive and significant in $1 \%$ significance level. And the coefficient of the illiteracy rate is negative and significant in $1 \%$ significance level too. So taking the control variables into consideration can improve the significance level of the model. In line 4, the regression model is time and regional fixed effect model with controls. This is our preferential model. These tell us that if the Internet development index increases 0.1 , the real value of gross domestic product (GDP) will average increase $2.5 \%$, which is in accord with the trend showed by the scatter diagram mentioned before. What's more, we can find that when the human capital also plays an important role on the growth of real GDP. If illiteracy rate decreases 1\%, then GDP will average decrease by $9.28 \%$.

\subsection{Regression Analysis of Different Time Periods}

According to the basic regression, we find the internet has positive effects on economic growth, however, what we don't know how the effect change by the time. Therefore, it is necessary to make the regression analysis of different time period. Because there is temporary internet development decrease in 2010, so in order to exclude this gusty effect, we delete the year of 2010. We divided the 15 years into two periods: 2000-2006 and 20072014. The result is shown on Table 3. Every period is about 7 years.

From Table 3, comparing line 1 and line 2, the coefficient of the internet index in period of 2007-2014, 1.0578 , is bigger than 0.6745 . We can conclude that as time goes by and the accelerating of the Internet development, economic growth will obtain better promote.

Table 3. Regression analysis of different time periods.

\begin{tabular}{|c|c|c|c|c|}
\hline Dependent Variation & (1) 2000-2006 & (2) 2007-2014 & (3) 2000-2006 & (4) $2007-2014$ \\
\hline \multirow[t]{2}{*}{$\operatorname{lnk}$} & $0.5547^{* * *}$ & $0.3615^{* * *}$ & $0.2049^{* * *}$ & $0.0451^{* * *}$ \\
\hline & $(0.0377)$ & $(0.0257)$ & $(0.0392)$ & $(0.0136)$ \\
\hline \multirow[t]{2}{*}{$\operatorname{lnh}$} & $-0.1848^{* * *}$ & $-0.1694^{* * *}$ & $-0.0912^{* * *}$ & -0.0114 \\
\hline & $(0.0229)$ & (0.0309) & $(0.0335)$ & $(0.0399)$ \\
\hline \multirow[t]{2}{*}{ Internet index } & $0.6745^{* * *}$ & $1.0578^{* * *}$ & $0.4100^{*}$ & $0.4278^{* * *}$ \\
\hline & $(0.2061)$ & $(0.2158)$ & $(0.2150)$ & $(0.1094)$ \\
\hline \multirow[t]{2}{*}{ Market index } & $0.0652^{* * *}$ & $0.1008^{* * *}$ & -0.0013 & 0.0024 \\
\hline & $(0.0122)$ & $(0.0100)$ & $(0.0124)$ & $(0.0113)$ \\
\hline \multirow[t]{2}{*}{ lntech } & $0.3820^{* * *}$ & $0.3890^{* * *}$ & $0.6038^{* * *}$ & -0.0420 \\
\hline & $(0.0212)$ & $(0.0286)$ & $(0.1620)$ & $(0.0483)$ \\
\hline \multirow[t]{2}{*}{ lntrans } & $-0.3866^{* * *}$ & $-0.4065^{* * *}$ & $-0.6772^{* * *}$ & 0.0437 \\
\hline & $(0.0213)$ & $(0.0317)$ & $(0.1764)$ & $(0.0522)$ \\
\hline \multirow[t]{2}{*}{ Constant } & $1.7983^{* * *}$ & $2.8074^{* * *}$ & & \\
\hline & $(0.1886)$ & $(0.2193)$ & & \\
\hline Fixed effects & no & no & yes & yes \\
\hline $\mathrm{N}$ & 210 & 210 & 210 & 210 \\
\hline $\operatorname{adj} . R^{2}$ & 0.979 & 0.952 & 0.996 & 0.996 \\
\hline
\end{tabular}

Note: Standard errors in parentheses. ${ }^{*} \mathrm{p}<0.10,{ }^{* *} \mathrm{p}<0.05,{ }^{* * *} \mathrm{p}<0.01$ t. It is drawn by Stata. 


\section{Conclusion and Policy Implications}

This paper found that the Internet is in a high speed development in the 15 years of the $21^{\text {st }}$ century. Especially after 2006, all kinds of data have a leap growth and their growth speeds up obviously since 2000. At the same time, according to the study about the influence of the Internet factors on economic growth, we found that the Internet had become one of new momentum for Chinese economic growth. The basic conclusions are as follows.

Firstly, China's Internet development is very fast and on a very good trend. As of December 2015, Chinese Internet netizen reached 688 million, Internet penetration rate reached 50.3\%, and residents of Internet users in China had been more than half. Among them, 39.51 million Internet users were created in 2015, the growth rate of $6.1 \%$ had been up to the rate of $1.1 \%$ until 2014, and the scale of Internet growth is improved [16].

Secondly, the Internet has a significant impact on Chinese economic growth. According to the regression model of time and regional fixed effect model with controls, we can find that if the Internet development index increases 0.1 , the real value of gross domestic product (GDP) will average increase $2.5 \%$, which is in accord with the trend showed by the scatter diagram mentioned before. What's more, we can find that when the human capital also plays an important role in the growth of real GDP, if illiteracy rate decreases 1\%, then GDP will average decrease by $9.28 \%$.

Thirdly, the promoting effect on the economy of the Internet is still growing. According to the Regression analysis of different time periods, the coefficient of the internet index in period of 2007-2014, 1.0578, is bigger than the coefficient of the internet index in period of 2000-2007, 0.6745.

Based on the above research, this paper puts forward the following suggestions.

Firstly, we should continue to increase the Internet Communication Technology infrastructure construction investment, such as China's broadband investment and so on.

Secondly, we should improve the education investment mechanism, optimize the settings of professions, and try to cultivate more informationization talented person for the Internet + time. This paper has shown that human capital plays an important role in economic growth under the background of in the era of Internet +, so efforts should be made to improve the human cultivation mechanism, and realize the benign interaction of human capital, the internet communication technology and economic growth.

Despite important and significant findings, this study suffers from a number of limitations.

First of all, the using of Cobb-Douglas model evaluating the contribution of each factor to economic growth needs to improve, and the processing of production function model and index, and factor contribution measure on such issues need further exploration.

Second, the development of the Internet itself is a complex and multifaceted problem. It is also a dynamic problem. With the development of the technology and time, there will have more and more update content. This article just selects the number of Internet users, websites and the domain names to measure the level of the Internet development. Some other factors should be taking into consideration. So this index has yet to be perfected and has to improve.

\section{Acknowledgements}

I am really grateful to the anonymous referees whose comments have significantly improved this paper.

\section{References}

[1] Ren, B.P., Han, L. and Cui, H.M. (2015) The Measure of Chinese Provincial Economic Growth in the "New Normal” Economy State. Statistics \&Information Forum, No. 8, 24-33.

[2] Haywood, T. (1998) Global Networks and the Myth of Equality: Trickle Down or Trickle Away? Cyberspace Divide Routledge, No. 1, 32-41.

[3] Kim, S.E. (2013) Policy and E-government: Theories and Strategies. Bumnoonsa, Seoul, 12-22.

[4] Lasswel, H.D. (1971) A Pre-View of Policy Science. Elsevier Publishing, New York, American, 124-135.

[5] Pohjola, M. (2000) Information Technology and Economic Growth: Across-Country Analysis. UNU-WIDER Institute for Development Economics Research, Working Paper No. 173, 1. http://www.wider.unu.edu/publications/working-papers/previous/en_GB/wp-173/_files/82530864586827164/default/w p173.pdf

[6] Chu, N. (2005) ICT and Causality in the New Zealand Economy. General Information, No. 1, 48-57. 
[7] Neira, I. (2007) Capital Human Desarrollo Economic Mundial: Models Econometricosy Perspectiva [Human Capital and Global Economic Development: Econometric Models and Perspectives]. Estudios Económicos Desarrollo Internacional, 7, 53-80.

[8] West, D.M. (2011) Technology and the Innovation Economy. Brookings, Washington DC.

[9] Salahuddin, M. and Alam, K. (2015) Internet Usage, Electricity Consumption and Economic Growth in Australia: A Time Series Evidence Telematics and Informatics, 32, 862-878. http://dx.doi.org/10.1016/j.tele.2015.04.011

[10] Teng, L., Wang, Z., Pang, L. and Li, G.Q. (2006) Impact of Informatization on Chinese Regional Economy. Human Geography, No. 1, 72-75.

[11] Zhang, Y. and Li, Q. (2008) The Influence of ICT on Chinese Provincial Economic Development. Shanxi Financial Newspaper, No. 6, 38-44.

[12] Liu, Y. (2010) Transportation Infrastructure Investment, Regional Economic Growth and Spatial Spillover Effect. Chinese Industrial Economy, No. 12, 37-46.

[13] He, Z., Wu, Z.D., Chen, X. and Lv, T.Y. (2014) Impact of Braodband on China's Economic Growth. Journal of Beijing University of Post Telecommunication, No. 15, 82-86.

[14] Zhang, Y. (2014) The Influences of Internet Development on China's Economic Growth. Anhui University, Anhui, $1-69$.

[15] Liu, H. and Zhang, J.P. (2016) The Impact of ICT on Chinese Provincial Economic Growth. Statistics \& Information Forum, No. 12, 73-78.

[16] CNNIC Published $37^{\text {th }}$ China Internet Network Development State Statistic Report. http://tech.sina.com.cn/chart/20160122/095043.shtml

\section{Submit or recommend next manuscript to SCIRP and we will provide best service for you:}

Accepting pre-submission inquiries through Email, Facebook, LinkedIn, Twitter, etc.

A wide selection of journals (inclusive of 9 subjects, more than 200 journals)

Providing 24-hour high-quality service

User-friendly online submission system

Fair and swift peer-review system

Efficient typesetting and proofreading procedure

Display of the result of downloads and visits, as well as the number of cited articles

Maximum dissemination of your research work

Submit your manuscript at: http://papersubmission.scirp.org/ 